\title{
Meio AMBIENTE E LITERATURA
}

\author{
Marli Fantini Scarpelli \\ $\mathrm{UFMG}^{1}$
}

\begin{abstract}
RES U M O
Este artigo busca reconhecer alguns pontos de tangência entre os romances Vidas secas, de Graciliano Ramos, As cidades invisiveis, de Italo Calvino, e Grande sertão: veredas, de Guimarães Rosa, sobretudo no que respeita às relações modalizantes entre literatura e meio ambiente. Em meio à diversidade temática das obras indicadas, subjaz o tema da consciência ambiental, que, nas últimas décadas, vem recebendo a crescente adesão não apenas de ambientalistas, mas também de intelectuais, políticos, escritores. O foco na degradação ambiental, no alerta implícito acerca das precárias condições de vida futura em nosso planeta revela um dos nucleares e contundentes problemas a desafiar a agenda contemporânea. Nesse sentido, revela-se paradigmático o "lugar-sertão" rosiano, que, ao difundir seu território, seus valores e denúncias, patenteia uma concepção ambiental inovadora e reticular, em estreito diálogo com as atuais pesquisas interdisciplinares sobre o tema, as quais deveriam doravante guardar, em seu horizonte de expectativa, os paradigmas, as perspectivas e os equacionamentos que alicerçam as artes em geral e a literatura em particular.
\end{abstract}

\section{PALAVRAS - CHAVE}

Meio ambiente. Literatura. Modernidade.

\section{REALIDADE, FICÇÃO E SUAS INTERFACES}

Investir em redes de conhecimento e suas respectivas formas de expressão é um procedimento que vem paulatinamente demandando planejamentos, novas tecnologias - incluindo a espacial - e, mais importante, a mudança de pesquisas e currículos universitários. Tudo isso, sem dúvida, tem implicado o desenvolvimento e a adoção de metodologias complexas de caráter interdisciplinar e mesmo transdisciplinar. ${ }^{2}$ Tais

\footnotetext{
${ }^{1}$ Marli Fantini Scarpelli é pesquisadora do CNPq com bolsa de Produtividade em Pesquisa, graças à qual foi possível realizar este trabalho.

${ }^{2}$ Ver a respeito o artigo 3 da Carta da transdisciplinaridade, editada em 1994, por Basarab Nicolescu: "A transdisciplinaridade é complementar à abordagem disciplinar; ela faz emergir do confronto das disciplinas novos dados que as articulam entre si; e ela nos oferece uma nova visão da Natureza e da Realidade. A transdisciplinaridade não busca o domínio de várias disciplinas, mas a abertura de todas elas àquilo que as atravessa e ultrapassa". Disponível em: www.autonomia.com.br/proposta/transdisciplinariedade.php. Acesso em: 17 jun. 2007.
} 
abordagens se aplicam tanto em âmbitos mais restritos - conferências de especialistas ou de universidades e empresas - como também em esferas mais amplas, a exemplo de governos ou organizações nacionais e supranacionais, como ONU e UNESCO. Estas, segundo se sabe, vêm investindo sistematicamente em pesquisas, debates, equacionamentos e até cobranças relativas ao controle do aquecimento global, à distribuição mais equânime da renda em países em desenvolvimento ou à preservação de recursos naturais.

Este é, pois, um tema nuclear para questões relativas a preservação, subsistência e sustentabilidade dos espaços habitáveis. No extremo, frente ao risco de sobrevivência da humanidade, os pesquisadores desse campo têm-se mostrado, de algum modo, sensíveis à questão e, ainda que não se mobilizem diretamente, contribuem, numa certa medida, quando tratam crítica ou teoricamente do assunto, desencadeando, dessa forma, um efeito multiplicador de perguntas, respostas e buscas de solução.

Assim sendo, a degradação ambiental, as condições precárias de saúde e as condições de vida futura em nosso planeta são apenas alguns dentre os problemas contundentes que desafiam as pesquisas e as artes contemporâneas. Redes complexas de informação, foros de discussão em níveis locais, nacionais e internacionais, sofisticados processos de comunicação com índices de recorrência antes incomuns investem em recursos interdisciplinares e transdisciplinares na busca de solução para os desafios que afloram junto com o nascente milênio. Trata-se de distintos investimentos que hoje se difundem em praticamente todas as esferas irradiadoras de conhecimento, imaginação e cultura no planeta. É possível identificar, nesse quadro, formas contemporâneas de interatividade, visando a diversas formas de investigação, investimento, desenvolvimento de novos paradigmas e de melhores condições de sua aplicação. Essa já seria uma razão suficiente para associar meio ambiente, em seu sentido mais amplo, à literatura e às outras artes, bem como à cultura e às ciências.

Semelhante associação pressupõe o desafio de desenvolver uma ampla e responsável consciência ambiental, reconhecer e, em alguns casos, preservar inter-relações criativas do homem com o espaço vital, ou seja, a interação de meio ambiente, cultura e literatura, com abertura a outras manifestações de arte e às diversificadas formas de conhecimento que equacionam o tema. É inegável a contribuição desse agenciamento coletivo e transdisciplinar para a melhor compreensão da diversidade do mundo contemporâneo e para a geração de meios capazes de sancionar reflexões, redimensionamento e aperfeiçoamento do meio ambiente, visando, desse modo, a formas ágeis, remanejáveis e adequadas de adaptação da vida a um universo de rápidas e inesperadas transformações.

O universo se desloca, e, conforme já se destacou, inumeráveis são as buscas de novas alternativas por parte de órgãos de pesquisa, laboratórios, indústrias, com vista à ampliação e aplicabilidade de conhecimentos sobre melhores condições de vida e sustentabilidade do meio ambiente. Embora pouco conhecido, um órgão significativo nesse sentido é o INPE - Instituto Nacional de Pesquisas Espaciais, que realiza, no Brasil, pesquisas concernentes às ciências atmosféricas, observação da Terra, engenharia e tecnologia espacial. Pesquisadora do assunto, a Profa. Vânia Maria Nunes dos Santos (ECA-USP) postula a necessidade de "ir ao espaço para compreender e buscar soluções para os problemas da terra”. É dela a convicção de que, graças à tecnologia espacial do "sensoriamento remoto", desponta uma nova e complexa ferramenta, com um grande leque de possibilidades de 
atuação nas áreas de florestas, agricultura, geologia, oceanografia, clima, planejamento urbano, enfim, "para a realização de planejamento socioeconômico, monitoramento do meio ambiente e levantamento dos recursos naturais renováveis e não renováveis do planeta”. Tendo ainda em vista a possibilidade de aplicação escolar dos conhecimentos veiculados em sua pesquisa, a professora defende a socialização da ciência e da tecnologia espacial sob o argumento de que, assim se fazendo, podem-se implementar, em escala sociocultural mais ampla, o uso e as aplicações "para a tomada de decisões economicamente sustentáveis, socialmente justas e politicamente viáveis para o desenvolvimento da sociedade como um todo e para a busca de melhoria de qualidade de vida". ${ }^{3}$

Pesquisas como a mencionada, acerca de melhores condições de vida, relacionamento e sobrevivência do homem na Terra e, mais recentemente, de sustentabilidade, sempre estiveram, de algum modo, em correspondência com a literatura. Isso se explica, sobretudo, pelo olhar múltiplo de que a literatura se dota, mostrando-se ela capaz, a partir de sua perspectiva diferencial, de conferir a complexidade de focos necessária para se ler a diversidade e a mutabilidade do mundo. Ela se dotaria, nesse sentido, da potência oracular de antecipar imaginários e transformações negativas, como degradações, desastres, guerras, dominações, hecatombes, mudanças climáticas relevantes, que poderiam, caso ela fosse ouvida (ou lida), ser evitadas. Importa obviamente salientar a propriedade positiva que possui a literatura em prever riquezas, novas formas de alimentos, sustentabilidade, saúde, a serem potencializadas em benefício do homem, do meio ambiente, da vida.

Grande parte dos fenômenos que regulam ou desregulam nosso meio ambiente são-nos muitas vezes imperceptíveis. Isso porque não nos é dado ver ou assimilar certas ocorrências que - dentre outros motivos -, ao fugir de sua ordem habitual, causam-nos mal-estar ou mesmo inquietação. Em razão de tais limites, as grandes aporias, como o tempo, a morte, as hecatombes, acabam por se tornar invisíveis e intraduzíveis à maior parte das pessoas e, em grande parte, responsáveis pelo entrave nas criações e reflexões de ordem científica, filosófica ou mesmo política.

Ao longo da história da humanidade, a literatura tem-se muitas vezes mostrado, mais do que outras formas de conhecimento, capaz de representar o irrepresentável ou o indizível. Ou seja: dota-se da potência de traduzir aquilo que outras linguagens não são capazes de expressar. Assim sendo, graças às virtualidades imagéticas da criação literária, torna-se-lhe possível dar materialidade e visibilidade àqueles elementos que, doutra forma, seriam intraduzíveis e imperceptíveis a olho nu. Trata-se de elementos sutis, constitutivos da interface oculta entre realidade e imaginação, natureza e cultura.

Roland Barthes, crítico literário e pensador francês, afirmava, em aula inaugural na Universidade de Sorbonne, que a Literatura é o "fulgor do real". De fato, a realidade não é registrável em todas suas variantes, nem em sua totalidade, ou, simultaneamente, em todos os tempos e lugares. Barthes quer dizer com isso que o que chamamos de realidade se dá a ver somente através da literatura (acrescentaríamos outras artes, como o cinema, as pinturas, ou narrativas históricas). Vale dizer que, ao representar uma imagem do mundo sensível, a literatura confere a este a materialidade que ele, por si só, não possui ou possui parcialmente. Para Barthes, isso é possível justamente porque sendo

${ }^{3}$ http://www.eca.usp.br/nucleos/nce/pdf/161.pdf. 
verdadeiramente enciclopédica, a literatura faz girar os saberes, não fixa, não fetichiza nenhum deles: ela lhes dá um lugar indireto, e esse indireto é precioso. Por um lado, ele permite designar saberes possíveis - insuspeitos, irrealizados: a literatura trabalha nos interstícios da ciência [...] A ciência é grosseira, e a vida é sutil, e é para corrigir essa distância que a literatura nos importa. ${ }^{4}$

De fato, Barthes acredita na capacidade da literatura em dar um contorno à realidade, corrigi-la ou transformá-la. Ele defende que, no interior de um mesmo idioma, afloram várias línguas, cada uma das quais sendo capaz de traduzir distintos desejos. Ao declarar a potência da literatura, ele postula a necessidade de a língua literária divergir da língua meramente informativa, a língua "de toda a gente", sob o pressuposto literário de Mallarmé, e, respectivamente, o político de Karl Marx, de que só se pode mudar o mundo mudando a língua. Ou, conforme seu profetismo em relação à escritura (escrita do sujeito por Barthes enunciada no espaço da literatura): "Mudar a língua', expressão mallarmeana, é concomitante com 'Mudar o mundo', expressão marxiana; existe uma escrita política de Mallarmé, daqueles que o seguiram e o seguem ainda". ${ }^{5}$

Curiosamente, Guimarães Rosa, em entrevista concedida a Gunter Lorenz, no contexto do 1ํ Congresso de Escritores Latino-Americanos, de janeiro de 1965, em Gênova, defende, não diferentemente de Barthes, a potência criadora da literatura. Enquanto "escritor", Rosa postula a necessidade de diferença cultural da América Latina, além de pleitear para a literatura produzida no continente um lugar ao sol na tradição canônica. É ainda deste locus de enunciação que ele pronuncia sua crença na função utópica da arte e, portanto, no papel transformador da literatura e do escritor:

minha língua brasileira é a língua do homem de amanhã, depois da purificação. Por isso devo purificar minha língua. Minha língua [...] é a arma com a qual defendo a dignidade do homem $[\ldots]$. Somente renovando a língua é que se pode renovar o mundo. ${ }^{6}$

"O ser humano não pode suportar muita realidade" é um verso em que o poeta T. S. Eliot, em visível afinação com semelhantes reflexões, concebe a arte poética como um suplemento simbólico, alternativo e maleável da realidade, ou seja, um contraponto possível à inassimilável crueza e intraduzibilidade do real. De fato, quando a história do homem ou a descrição geopolítica do mundo trazem, sob sua forma de enunciação, um novo arranjo das interpretações fixas, acena-se para a possibilidade de mudar sua agenda.

\section{REDES SISTÊMICAS E ECOSSISTEMA}

Uma privilegiada base do conhecimento contemporâneo são as redes. Por que as redes? Porque além de tecer, matizar, cruzar, entrecruzar, multiplicar, as redes estabelecem relações e intersecções, desencadeiam conexões entre o que está desconectado. Em âmbitos mais sofisticados, as redes mostram-se aptas a afinar, agenciar e gerenciar relações complexas. Sob o pressuposto básico de que são as redes que constituem o padrão de organização de todos os seres vivos, comunicações, pensamentos, crenças, filosofias, literatura e as demais

\footnotetext{
${ }^{4}$ BARTHES. Aula, p. 18-19.

${ }^{5}$ BARTHES. Aula, p. 24.

${ }^{6}$ ROSA. Ficção completa, p. 52.
} 
artes, são elas também responsáveis por alicerçar o pensamento sistêmico ou a abordagem por sistemas. Trata-se de uma estrutura de pensamento extremamente atual, que se vê empregada na literatura, na economia, na cultura, nos sistemas digitais, nas relações globais. Aliando a estrutura reticular (estabelecida por redes) à de "ecossistema”, Fritjof Capra estabelece o seguinte conceito:

Os ecossistemas são compreendidos em termos de teias alimentares (ou seja, de redes de organismos); os organismos são redes de células, e as células são redes de moléculas. A rede é um padrão comum a todas as formas de vida. Onde existe vida existem redes. ${ }^{7}$

Também tecidas como redes são as comunicações que, ao criar pensamentos e significados, geram pensamentos, comunicações e significados novos. Assim sendo, ao se reproduzirem, tanto as redes que organizam sistemas vivos quanto as redes comunicacionais são regidas pelo processo de auto-referencialidade. Nessa perspectiva, toda experiência, toda arte, todo pensamento estão continuamente interagindo consigo mesmos e uns com os outros, realimentando-se e interferindo na rede mais ampla e mais dinâmica de vida e sociedade. Ao levarmos em conta que o "sistema" é um conjunto de elementos e relações que se orientam para diversos tipos de finalidade, o pensamento sistêmico pode ser caracterizado como o constituir, o operar, o transformar do referido sistema, possibilitando-lhe atuar por diferenças, por projetos, por realidade concreta, vivenciada, imaginária, virtual. Isso posto, ao se levar em conta que as comunicações acontecem em redes socioculturais, não é difícil inferir que elas têm aptidão para produzir sistemas compartilhados de valores, pensamentos, explicações, crenças. Se, de um lado, esse modo de operar tem a capacidade de originar novas comunicações, de outro, não lhe faltará competência para conferir aos indivíduos (enquanto membros de uma espessa e interativa estrutura reticular) uma espécie de identidade migrante e compartilhada.

O ser humano tende a buscar sentido e significados em suas experiências e sentimentos. Essa busca será tanto mais eficaz quanto mais os sentidos e significados forem recursivamente realimentados por outras experiências, outros conhecimentos, outros sentidos. Contudo, essa tendência conduz a uma questão complexa: o universo se transforma, o pensamento, as ciências, as artes se complexificam, e é previsível que, assim sendo, se operem mudanças nas formas de representação, compreensão e atuação do ser humano. Isso posto, deve-se ter em vista que, para a abordagem de questões complexas, torna-se de capital relevância a adoção de um pensamento complexo, que ganha especial acento a partir da Teoria da Complexidade, que, segundo Capra, é imprescindível para o progresso do pensamento sistêmico.

Tal progresso vem gerando a demanda do estudo da forma, ou seja, de padrões e relações, justamente porque a principal ênfase da Teoria da Complexidade está nos padrões. Capra defende a necessidade de desenvolver e aplicar essa nova teoria, em razão de ser ela essencialmente uma matemática dos padrões e, desse modo, com relevância para o pensamento sistêmico ou reticular. ${ }^{8}$ Não diferentemente de inúmeros pensadores e artistas de distintas

\footnotetext{
${ }^{7}$ CAPRA. Alfabetização ecológica: o desafio para a educação no século XXI, p. 23.

${ }^{8}$ Capra salienta a importância dos "padrões" que, dentre outros, englobam os "atratores estranhos" da "teoria do caos" e os "fractais" da geometria moderna. CAPRA. Alfabetização ecológica: o desafio para a educação no século XXI, p. 24.
} 
épocas, Capra acredita que "as artes podem ser um instrumento poderoso para ensinar o pensamento sistêmico, além de reforçarem a dimensão emocional que tem sido cada vez mais reconhecida como um componente essencial do processo de aprendizagem".

Empregando paradigmas homólogos aos da Teoria da Complexidade, a ecologia tem, por sua vez, o objetivo de estudar os vários seres vivos em suas relações mútuas e com o meio ambiente. Jean Tricard, estudioso da ecologia, afirma, em homologia a Capra, que o conceito de sistema é, atualmente, o melhor instrumento lógico de que dispomos para analisar os problemas do meio ambiente. Nesse sentido, ele alerta que, sendo o ecossistema um conjunto de seres vivos mutuamente dependentes uns dos outros e do meio ambiente no qual vivem, a adoção do conceito de sistema pela ecologia possibilitou a integração de conhecimentos anteriormente isolados, adoção que "permitiu o desenvolvimento de uma nova maneira de abarcar problemas". ${ }^{10}$ Esse desenvolvimento deve ser levado em conta, em razão da crescente intervenção do homem no meio ambiente, e da resposta deste à ação daquele. Esse é um indicador de que o conhecimento acumulado pela civilização humana não deve operar no sentido de indispor a cultura contra a natureza, mas, antes, integrá-las, tendo sempre, em seu horizonte, a manutenção da trajetória humana no curso da vida.

$\mathrm{Na}$ organização das sociedades complexas, o campo simbólico nunca é maniqueísta ou unilateralmente separado em certo e errado, bem e mal, hegemonia e subalternidade, sendo estes critérios excludentes, herdados de concepções simplistas, imobilizadoras e hierarquizantes, oriundas do pensamento positivista e eurocêntrico. Trata-se antes de uma forma de organização arquitetada sob pilares múltiplos e diversificados, os quais, além de relativizar pólos dicotomizados, servem de suportes a "sistemas entrelaçados de oposições, de ambivalências, de significados múltiplos que os atores [socioculturais] buscam submeter aos seus objetivos para dar sentido às suas ações." ${ }^{11}$ Em suas formulações sobre os movimentos sociais em sociedades complexas, Alberto Melucci defende que tais movimentos "são redes submersas de grupos, de pontos de encontro, de circuitos de solidariedade que diferem profundamente da imagem do ator coletivo politicamente organizado". As sociedades que apresentam alta complexidade possuem uma estrutura segmentada, reticular, policéfala - uma estrutura "submersa", ou seja, de latência. Nesse tipo de sociedade,

cada célula vive uma vida própria, completamente autônoma do resto do movimento, mesmo mantendo uma série de relações através da circulação de informações e de pessoas; estas relações se tornam explícitas somente em ocasião de mobilizações coletivas e de saídas em torno das quais a rede latente ascende à superfície, para então mergulhar-se de novo no tecido cotidiano. A agregação tem caráter cultural e se situa no terreno da produção simbólica na vida cotidiana. ${ }^{12}$

Atento ao crescente inter-relacionamento das aspirações pessoais com os anseios da coletividade, Melluci considera quase impossível abordar separadamente a solidariedade coletiva das buscas pessoais, as necessidades efetivas e comunicacionais dos componentes

\footnotetext{
${ }^{9}$ CAPRA. Alfabetização ecológica: o desafio para a educação no século XXI, p. 25.

${ }^{10}$ TRICART. Ecodinâmica, p. 17-19.

${ }^{11}$ MELUCCI. A invenção do presente, p. 75.

${ }^{12}$ MELUCCI. A invenção do presente, p. 97.
} 
desses grupos. Considerando que os processos de subjetividade, subjetivação e intersubjetividade se constroem a partir da interatividade entre seres e culturas, para lograrem êxito, as relações devem levar em conta a heterogeneidade e a abertura a freqüentes remanejamentos.

\section{LITERATURA E REDES: DESCONSTRUÇÃO E RENOVAÇÃO DAS 1001 CIDADES INVISÍVEIS, DE CALVINO}

Ao propor um modelo de literatura para o próximo milênio, Italo Calvino elege, como ideal, o romance complexo e multíplice, capaz de substituir a unicidade de um eu pensante pela diversidade de sujeitos, vozes e perspectivas. Semelhante romance, concebido como hipertexto, deve conjugar, em sua totalidade aberta e infinita, diversos saberes e códigos, numa visão plural e multifacetada do mundo. Arquitetado como uma grande rede, tal romance é um universo onde cada vida se representa como uma enciclopédia aberta, uma biblioteca, um inventário de objetos, de informações, de leituras, com amostragem de estilos. Em suas páginas, tudo pode ser remexido e reordenado de todas as maneiras. Mesmo nos textos breves ou nos episódios de um romance, cada objeto mínimo é concebido como o centro de uma rede de relações de que o escritor não consegue se esquivar, multiplicando os detalhes a ponto de suas descrições e divagações se tornarem labirínticas e intermináveis. De qualquer ponto que parta, o discurso se alarga e se complexifica, de modo a compreender horizontes cada vez mais vastos, os quais, podendo desenvolver-se em todas as direções, chegariam a abraçar o universo inteiro. ${ }^{13}$

A idéia de integrar, numa mesma rede proliferante e interminável, conhecimento e emoção, várias experiências e estilos, onde tudo pudesse ser continuamente remexido e reordenado sob todas as formas e concepções, engendra, segundo Calvino, a totalidade potencial, conjectural e multíplice dos hiper-romances emblemáticos da literatura deste novo milênio. Essa radiografia do hiper-romance como grande rede pode ser reconhecida nas próprias construções literárias de Calvino, dentre as quais As cidades invisíveis, ${ }^{14}$ obra estruturada como um diálogo entre Marco Polo e Kublai Khan, ambos personagens oriundos de um outro livro, O livro das maravilhas, de Marco Polo, inspirador de Cristóvão Colombo em suas viagens e descobertas. ${ }^{15}$

Em As cidades invisíveis, Marco Polo é um personagem que, figurando como o embaixador de Kublai Khan, traz a este notícias atualizadas do império mongol e de um mundo que não pára de crescer e modificar-se. Espécie de tradutor dos cenários por onde circula, Polo desoculta para o imperador mongol os signos da viagem, das trocas simbólicas e culturais, enfim, da matéria-prima que lhe serve de suporte para a arquitetura, os traçados urbanos e as redes de circulação das cidades "invisíveis" que ele vai, simbólica e imaginariamente, cartografando para Khan. Este, por seu turno, só conhece os próprios domínios pelo traçado do Atlas ou pelo jogo de xadrez onde, enquanto ele e Polo dialogam, as peças se deslocam como as cidades móveis, em contínua transmigração e mudança. Desejando

\footnotetext{
${ }^{13}$ CALVINO. Seis propostas para o próximo milênio, p. 122.

${ }^{14}$ CALVINO. As cidades invisiveis.

${ }^{15}$ POLO. O livro das maravilhas.
} 
conhecer o oculto de seu império, Khan convoca o mercador estrangeiro e lhe pede que lho traduza: "O imperador é aquele que é estrangeiro para cada um de seus súditos e somente por meio de olhos e ouvidos estrangeiros o império podia manifestar sua existência para Kublai". ${ }^{16}$

Calvino deixa entrever em seu livro que, somente pela fina e tênue linha da narrativa, a história pode se renovar e sobreviver à decadência, à ruína, à pulverização nas teias do tempo. Na passagem abaixo, advém a Kublai Khan a consciência da efemeridade e da perecibilidade do seu cetro, seu poder, seu castelo, seus domínios, da realidade, enfim. Contudo, ao mesmo tempo, ele "aprende", através das narrativas poéticas de Marco Polo, que, não obstante a finitude e as perdas, ele pode contar com o único poder que nos salva da dissolução e do desaparecimento. Trata-se do poder de preservação de que se dota a literatura, cujo valor simbólico a torna infensa às "mordidas dos cupins". Sob nova mirada, o poderoso imperador mongol pode equacionar o

desesperado momento em que se descobre que este império que nos parecia a soma de todas as maravilhas é um esfacelo sem fim e sem forma, que a corrupção é gangrenosa demais para ser remediada pelo nosso cetro, que o triunfo sobre os soberanos adversários nos fez herdeiros de prolongadas ruínas. Somente nos relatórios de Marco Polo, Kublai Khan conseguia discernir, através das muralhas e das torres destinadas a desmoronar, a filigrana de um desenho tão fino a ponto de evitar as mordidas dos cupins. ${ }^{17}$

Polo tece uma rede deslizante de histórias/cidades com nomes femininos: Anastácia, Diomira, Despina, Isidora, Tâmara, Zaíra... um catálogo tão extenso de nomes quanto de cidades. Estas se mesclam e se metamorfoseiam umas nas outras, uma começa onde outra termina, com ramificações intercambiáveis e infinitas. São cidades que perdem o estatuto topográfico e referencial em proveito do simbólico e metafórico, em correspondência com este verso de Carlos Drummond de Andrade: "Cada cidade tem sua linguagem nas dobras da cidade transparente". Os fios da memória de "Zaíra", por exemplo, vão sendo tecidos ao mesmo tempo e no mesmo ritmo em que os velhos marinheiros remendam as redes e contam pela milésima vez a mesma história. Assim, a "cidade se embebe como uma esponja dessa onda que reflui das recordações e se dilata". ${ }^{18}$

A partir das travessias poéticas de Polo e Khan, o império é descentrado, pulverizandose, arruinando-se e inesperadamente florescendo em outros espaços e temporalidades. Inaudito é o fato de o imperador mongol percorrer todo o seu gigantesco império sem sair da sede: tudo se desenha na interface entre a profundidade de seus domínios e a superfície do mapa. Função relevante possui, nesse sentido, o tabuleiro de xadrez, por meio do qual os dois interlocutores manejam peças que se movimentam e se reordenam juntamente com a descrição das cidades: as já desaparecidas, as virtuais, as desdobráveis, num catálogo de nomes e formas intermináveis. Pelo Atlas/tabuleiro/narrativa, podem-se atravessar fronteiras de continentes e reinos, enredando-se e entrecruzando-se cidades extemporâneas e irredutíveis umas às outras, a exemplo de São Francisco, que, localizada no império norteamericano, patenteia-se anacrônica ao tempo e à perspectiva de Khan.

\footnotetext{
${ }^{16}$ CALVINO. As cidades invisiveis, p. 25.

${ }^{17}$ CALVINO. As cidades invisíveis, p. 9-10.

${ }^{18}$ CALVINO. As cidades invisiveis, p. 14.
} 
Semelhantes deslocamentos de territórios, poderes e temporalidades surpreendem no sentido de equacionar e relativizar a ingênua pretensão de que os impérios ou mesmo os valores neles implicados possam durar eternamente. Dessa forma, somos instados a refletir sobre a perecibilidade de impérios hegemônicos, a exemplo do mongol ou do norte-americano, cujo declínio começa a dar seus primeiros sinais, como podemos entrever na passagem abaixo.

Mas, falando de Tróia, ele lhe atribuía a forma de Constantinopla, e previa o assédio com o qual por alguns meses a comprimiria Maomé que, astuto como Ulisses, faria rebocar os navios à noite $[\ldots]$ E da mistura dessas duas cidades resultava uma terceira, que podia chamar-se São Francisco e propender pontes longuíssimas e leves [...] e florescer como capital do pacífico dali a um milênio, depois do longo assédio de trezentos anos que levaria a raça amarela e negra e vermelha a fundir-se com a estirpe sobrevivente dos brancos, num império mais vasto que o do grande Khan. ${ }^{19}$

Marco Polo é súdito de Khan. Todavia, a linguagem empregada entre os dois não representa um modelo hegemônico ou dominador, mas de intercâmbio, de permuta. ${ }^{20} \mathrm{~A}$ não-prevalência cultural-antropológica na relação entre Khan e Polo é metaforizada no "jogo de xadrez", a partir de cujos lances surge a parceria entre ambos. Sob o deslizamento metonímico das peças do jogo, os sentidos do império circulam, e ele avança em novo significado: desloca-se, pois, do contexto tópico-ideológico para se inscrever no simbólico. As cidades invisíveis de Calvino se deslocam e um novo império desponta. Sem surpresa, pois, nas dobras do Atlas, descortina-se e entremostra-se um novo traçado: nas cidades sem fisionomia, produzidas em série, "nos lugares em que as formas exaurem suas variedades e se desfazem"; nos excessos de produção que se amontoam em cidades superpovoadas; nos formigueiros urbanos fotografados nos rostos indiferenciados, "num espaço limitado como o da plantação de milho, de quanta gente ela pode conter, especialmente se postos sentados com os braços em torno de joelhos, imóveis". ${ }^{21}$

O narrador do romance assinala: "O estrangeiro aprendera a falar a língua do imperador, ou o imperador a falar a língua do estrangeiro". 22 É de se notar que, pelo convívio e pela parceria, Khan aprende o segredo da narrativa, descobrindo-se estrangeiro a seus próprios domínios. A partir de então, produz arranjos, deslocamentos, inversões, reinvenções, traduções, um jogo de autoria/atoria; na verdade, um canto paralelo: quando desoculta o modo como o estrangeiro opera, ele próprio se torna um tradutor, que cria, com meios diferentes, efeitos análogos aos de Polo: ${ }^{23}$ "a mente do grande Khan partia, por conta própria, e, desmontando a cidade pedaço por pedaço, ele a reconstruía de outra maneira, substituindo ingredientes, deslocando-os, invertendo-os". ${ }^{24}$

\footnotetext{
${ }^{19}$ CALVINO. As cidades invisíveis, p. 125-126.

${ }^{20}$ Guilhermo Gucci demonstra que, diferentemente da postura eurocêntrica de que em geral se dotam as viagens de conquista realizadas por europeus, nas viagens de Marco Polo, e em suas relações com o imperador a quem serve como embaixador, patenteia-se não uma relação de domínio ou de superioridade, mas de intercâmbio/troca. Ver GUCCI. Viajantes do maravilhoso, p. 98-99.

${ }^{21}$ CALVINO. As cidades invisiveis, p.133.

${ }^{22}$ CALVINO. As cidades invisíveis, p. 42.

${ }^{23} \mathrm{O}$ uso de meios diferentes para a obtenção de efeitos análogos é formulada por Valéry no seu conceito de "tradução". Ver PAZ. Traducción: literatura y literalidad.

${ }^{24}$ CALVINO. As cidades invisiveis, p. 43.
} 
O imperador mongol não compreende o que é uma ponte. O mercador veneziano tenta explicar a Khan tal "maravilha tecnológica", cuja estrutura e cujos suportes a impedem de desabar. Todavia, considerando-se os limites de seus padrões de conhecimento, a ponte é para ele algo certamente anacrônico, incongruente e inassimilável. Para demonstrar a mobilidade do sentido e da estrutura da ponte, Polo emprega um pensamento reticular, em que recorre à complementaridade entre literatura e ciência:

Marco Polo descreve uma ponte, pedra por pedra.

- Mas qual é a pedra que sustenta a ponte? - pergunta Kublai Khan.

- A ponte não é sustentada por esta ou aquela pedra - responde Marco -, mas pela curva do arco que estas formam.

Kublai Khan permanece em silêncio, refletindo. Depois acrescenta:

- Por que falar das pedras? Só o arco me interessa.

Polo responde:

- Sem pedras o arco não existe.

As cidades invisíveis nos convidam a acompanhar uma viagem simbólica pela espacialidade móvel dos mapas e da história. Nesse percurso, deslocamo-nos por um semnúmero de modelos urbanos que guardam, em seu traçado, os signos da diversidade arquitetônica, lingüística e cultural do universo mediterrâneo, revelando também uma rede textual que tece a interface entre literatura, história, ciências, espaços, culturas e línguas.

\section{Literatura e meio ambiente em Vidas secas, de Graciliano Ramos}

Ao abordar questões relativas a espaço e meio ambiente, a literatura faz a integração ou o desajuste entre homem e natureza. De certa forma, ao preocupar-se com problemas de preservação e sustentabilidade de nosso planeta, ela não deixa de equacionar em que medida cada um desses elementos se vê limitado ou potencializado pelo outro. No Brasil, especialmente na primeira metade do século XX, a literatura modernista enfocou, muitas vezes de forma naturalista e cáustica, semelhante relação, sobretudo no meio rural. Com grande freqüência, serão enfocadas por essa literatura questões como o êxodo rural e a escravização imposta aos trabalhadores por coronéis dos grandes latifúndios, sobretudo do nordeste brasileiro.

Exemplo fulcral dessas relações pode ser reconhecido em Vidas secas, de Graciliano Ramos, lançado em 1938, ${ }^{25}$ no contexto do nosso modernismo. Em homologia ao recente fenômeno dos sem-terra, os personagens de Vidas secas invadem fazendas abandonadas por ocasião da estiagem, de onde, logo depois das primeiras chuvas, são semi-escravizados ou, na pior hipótese, expulsos, vendo-se, em seguida, obrigados a caminhar sem rumo, sob condições climáticas absolutamente cáusticas e portanto adversas a qualquer ser vivo. Eles saem à procura de uma terra prometida, que jamais será encontrada.

Nos treze capítulos do romance, são recorrente e circularmente retomadas as mesmas questões e carências, variando apenas as perspectivas, que vão sendo alternadamente assumidas por cada uma das personagens, um grupo familiar destituído de mistérios, esperanças ou desejos. Esmagadas pela brutalidade do clima, obrigadas a fugir da seca

${ }^{25}$ RAMOS. Vidas secas. A respeito deste romance, ver mais em CANDIDO. Os bichos do subterrâneo. 
ou a procurar morada em espaços alheios, semelhantes personagens se vêem compelidas a disputar, com sua cadela Baleia, os raros preás (ratos) encontrados em meio à caatinga e mesmo a devorar o papagaio que fazia parte da família, irônica e paradoxalmente sob o pretexto de que ele não falava: "Resolvera de supetão aproveitá-lo como alimento e justificara-se declarando a si mesma que ele era mudo e inútil. Não podia deixar de ser mudo. Originariamente a família falava pouco". ${ }^{26}$ Nesse universo de sequidão, fome, miséria sócio-econômica, não há como se expressarem desejos ou imaginação, em cujo lugar se sobrepõem instintos de sobrevivência, necessidade e submissão. A memória resume-se à dolorosa lembrança de fome, de seca e de injustiças, metonimizadas pelo corrupto cobrador de impostos do governo ou por um brutalizado soldado amarelo:

O que desejava... Ah! Esquecia-se. Agora [Fabiano] se recordava da viagem que tinha feito pelo sertão, a cair de fome [...]. Na beira do rio haviam comido o papagaio, que não sabia falar. Necessidade. Fabiano também não sabia falar. Às vezes largava nomes arrevesados, por embromação. Via perfeitamente que tudo era besteira. Não podia arrumar o que tinha no interior. Se pudesse... Ah! Se pudesse, atacaria os soldados amarelos que espancam criaturas inofensivas. ${ }^{27}$

Há uma espécie de adaptação "genética" dos viventes de Vidas secas ao meio ambiente. Ambos, em visível processo de interface, se integram em suas características tanto internas quanto externas. Não estranha, assim, o fato de Fabiano se identificar com as plantas enraizadas, com bichos, enfim, com uma matéria-prima árida e seres brutos que se mesclam à terra avermelhada como ele.

Fabiano, você é um homem, exclamou em voz alta [...] pensando bem, ele não era homem: era apenas um cabra ocupado em guardar coisas dos outros. Vermelho, queimado, tinha os olhos azuis, a barba e os cabelos ruivos; mas como vivia em terra alheia, cuidava de animais alheios, descobria-se, encolhia-se na presença dos brancos e julgava-se cabra.

Olhou em torno, com receio de que, fora os meninos, alguém tivesse percebido a frase imprudente. Corrigiu-a, murmurando:

- Você é um bicho, Fabiano.

Isto para ele era motivo de orgulho. Sim senhor, um bicho, capaz de vencer dificuldades. ${ }^{28}$

Em pleno século XXI, com grande incidência de guerras étnicas, religiosas e econômicas, resultando em deslocamentos massivos de várias partes do mundo, as personagens de Vidas secas seriam irredutíveis a qualquer forma de diferenciação, o que as identifica a quaisquer exilados de seu espaço vital, condenados ao sem-lugar da diáspora e da miséria. Curiosamente, a correspondência com povos diaspóricos é feita pelo protagonista, que, num raro momento de lucidez, relaciona (sob a mediação do narrador, através do emprego do discurso indireto livre) sua condição à dos judeus errantes: "A sina dele era correr mundo, andar para cima e para baixo, à toa, como judeu errante. Um vagabundo empurrado pela seca. Achava-se ali de passagem, era hóspede". ${ }^{29}$

\footnotetext{
${ }^{26}$ RAMOS. Vidas secas, p. 12.

${ }^{27}$ RAMOS. Vidas secas, p. 41.

${ }^{28}$ RAMOS. Vidas secas, p. 21.

${ }^{29}$ RAMOS. Vidas secas, p. 19. Ver mais a respeito do romance em CANDIDO. Os bichos do subterrâneo; LINS. Valores e misérias das vidas secas; MOURÃO. Estruturas.
} 
Embora Fabiano e sua família estejam plantados na terra, confundidos com o ambiente árido e ressequido, submetidos a limitações existenciais, lingüísticas e socioeconômicas, no final do romance parece haver uma saída utópica e humanizadora para eles. Fugindo de um novo ciclo de seca e mortes, eles partem para o "sul", à procura de condições humanas mais dignas:

Iriam para diante, alcançariam uma terra desconhecida. Fabiano estava contente e acreditava nessa terra, porque não sabia como ela era nem onde era. Repetia docilmente as palavras de sinhá Vitória, as palavras que sinhá Vitória murmurava porque tinha confiança nele. E andavam para o sul, metidos naquele sonho. Uma cidade grande, cheia de pessoas fortes. Os meninos em escolas, aprendendo coisas difíceis e necessárias. Eles dois velhinhos, acabando-se como uns cachorros, inúteis, acabando-se como uns cachorros, inúteis, acabando-se como Baleia. Que iriam fazer? Retardaram-se, temerosos. Chegariam a uma terra desconhecida e civilizada, ficariam presos nela. E o sertão continuaria a mandar gente para lá. O sertão mandaria para a cidade homens fortes, brutos, como Fabiano, sinhá Vitória e os dois meninos. ${ }^{30}$

A despeito da vaga e frágil formulação, a utopia de alcançar um espaço libertador motiva os "viventes" a continuar buscando nova alternativa de vida. No entanto, por trás dessa motivação, irrompe a perspectiva amarga e desesperançada do narrador, cuja consciência ambiental e histórica alerta o leitor para o beco sem saída de indivíduos como os de Vidas secas. Graciliano Ramos sugere justamente que a relação entre o homem e seu meio não se restringe a problemas meramente ambientais. O ecossistema de que faz parte a vida é muito mais amplo e complexo do que supõe nosso vão ambientalismo. Ao denunciar a subcondição em que vivem seres como os retratados em seu romance, Ramos desloca o foco de seus leitores, direcionando-o para as vidas secas e limitadas pelas condições de natureza, sociedade, educação, cultura. Na cidade grande, malgrado o processo civilizacional, o acesso à educação e ao trabalho, reproduz-se o mesmo labirinto, a mesma subumanidade, o mesmo emparedamento daqueles cuja situação é similar à de Fabiano. Como outros milhares de "judeus errantes", Fabiano vê frustrado seu "sonho feliz de cidade" e, num fugaz instante de consciência, pode constatar que, como a cadela Baleia, a ele e à mulher nunca lhes será dado um final feliz: "Eles dois velhinhos, acabando-se como uns cachorros, inúteis, acabando-se como Baleia. Que iriam fazer? Retardaram-se, temerosos. Chegariam a uma terra desconhecida e civilizada, ficariam presos nela". ${ }^{31}$

\section{Degradação ambiental em Grande sertão: veredas, de Guimarães Rosa}

Outro importante romance modernista que também trata, dentre outras questões, da relação entre homem e meio ambiente, é Grande sertão: veredas, de Guimarães Rosa. Embora editado em 1956, quase 20 anos depois de Vidas secas, guarda com este muitas afinidades temáticas e estruturais. Assim, a despeito de seu regionalismo já deslizar para o transregionalismo, ou, melhor dizendo, para a tensão entre o eu e o mundo, o regional

\footnotetext{
${ }^{30}$ RAMOS. Vidas secas, p. 159.

${ }^{31}$ RAMOS. Vidas secas, p. 159.
} 
e o universal, o romance rosiano não deixa de retratar problemas relativos à geopolítica da degradação ambiental, mais precisamente na região do cerrado, com especial acento no sertão de Minas Gerais. O narrador-protagonista de Grande sertão: veredas é Riobaldo, um fazendeiro "quase barranqueiro", aposentado da profissão de jagunço, mediante a qual encarnou a legendária figura do "Urutu Branco", quando chefe de jagunçagem.

O livro é uma espécie de reportagem poética resultante do testemunho pronunciado por Riobaldo a um forasteiro, um homem culto, de "suma doutoração", que, sabendo de sua fama como o grande "chefe Urutu Branco", vem entrevistá-lo, no afã de obter notícias do sertão arcaico, regido pela lei dos latifundiários e seus belicosos jagunços. Contudo, a única voz que se expressa no romance é a do ex-jagunço, como se esta fosse a hora e vez do sujeito subalterno pronunciar sua versão de uma história pessoal e coletiva, marcada por reificação, anomia, privação, violência, disputas, traumas, mortes e culpa.

Deslocando-se por vários campos de batalha, à mercê de fogos inimigos, Riobaldo sobrevive graças a seu corpo fechado, à sua habilidade no uso das armas e das palavras, mediante as quais tanto é capaz de produzir poesia quanto de contestar códigos e leis criados por latifundiários. Em correspondência com outros heróis míticos, ele é rebatizado com epítetos guerreiros ("Cerzidor", "Tatarana", "Urutu Branco"), que se sucedem e se alteram à medida que, a partir de suas façanhas e de seu pacto com o Diabo, ele vai mudando de patamar até se tornar um poderoso chefe de jagunços, conforme relata a seu entrevistador:

Um comanda é com o hoje, não é com o ontem. Aí eu era Urutu-Branco; mas tinha de ser o cerzidor. Tatarana, o que em melhor ponto alvejava. Medo não me conheceu, vaca! Carabina. Quem mirou em mim e eu nele, e escapou: milagre; e eu não ter morrido: milagremente. ${ }^{32}$

Não podemos deixar de abrir parênteses para equacionar a correspondência entre a ficção e a realidade documental, ou seja, entre os "campos" que irrompem da bruteza do "real" e os "campos gerais", onde ficcionalmente se localiza o "sertão-mundo" de Guimarães Rosa. Situados em campos de guerra, os jagunços do grande sertão rosiano são cabos de guerra, força de trabalho escravo dos grandes senhores de terra (e de gado). Trata-se de indivíduos submetidos, sem voz, posse, autonomia ou nome próprio, (des)identificados como os "fulão e sicrão e beltrão e romão - pessoal ordinário". ${ }^{33}$

A pretexto de proteger e mapear os grandes feudos, os jagunços travam, entre si, intestinas e encaniçadas lutas, numa constante e estreita divisão de fronteiras, sem que eles próprios, malgrado seu poder de fogo, usufruam das posses e dos privilégios dos grandes latifundiários, pelos quais são dominados e demarcados como gado. Esse processo de reificação se explicita em designações, como esta que é ouvida e registrada por Riobaldo Tatarana: "Só eu... ou você mesmo, Tatarana. Mas a gente somos garrotes remarcados". ${ }^{34}$ Riobaldo toma paulatinamente consciência da condição degradada de si mesmo e de seu grupo, sobretudo ao empreender a grande travessia do romance, ou seja, sua passagem da "experiência" para "a vivência", do "real" para o "relato". Isso feito, ele pode reconhecer e denunciar as condições objetais, fragmentárias, sem perspectivas ou saída, que o

\footnotetext{
${ }^{32}$ ROSA. Grande sertão: veredas, p. 543.

${ }^{33}$ ROSA. Grande sertão: veredas, p. 58.

${ }^{34}$ ROSA. Grande sertão: veredas, p. 398.
} 
reduzem histórica e culturalmente a "ser homem muito provisório". ${ }^{35}$ Um momento nuclear na constituição da autonomia de Riobaldo ocorre durante o julgamento de Zé Bebelo, inicialmente um representante do governo que persegue jagunços e depois um chefe de bando jagunço. Mestre de guerra de Riobaldo, Zé Bebelo é julgado segundo a "lei do sertão", pronunciada na passagem abaixo por Joca Ramiro, o mais emblemático dentre os chefes jagunços:

- Lhe aviso: o senhor pode ser fuzilado, duma vez. Perdeu a guerra, está prisioneiro nosso... - Joca Ramiro fraseou [...]

- O senhor veio querendo desnortear, desencaminhar os sertanejos de seu costume velho de lei...

- Velho é, o que já está em si desencaminhado. O velho valeu enquanto foi novo... ${ }^{36}$

O julgamento termina com a libertação de Zé Bebelo e a condenação da "lei" decretada pelos "velhos costumes" dos senhores de terras. A cosmovisão carnavalesca ${ }^{37}$ que impera nesse cenário transforma o mundo regido pelas inflexíveis e hegemônicas leis do latifúndio em um mundo desconcertado, um "mundo à revelia", segundo a expressão de Zé Bebelo. ${ }^{38}$ Reduzido à condição subalterna e condenado a ser, como os demais jagunços, um "homem muito provisório", sem nome próprio, sem direito a voz e voto, Riobaldo, entretanto, intervém, com uma fala impactante e renovadora, no discurso sentencioso de Joca Ramiro, produzindo assim uma reviravolta do julgamento. Bebelo é libertado, e doravante os grandes chefes iniciam guerras fratricidas que desembocam no assassinato de Ramiro, o maior e mais poderoso dentre os chefes jagunços. Essa morte é entendida por Riobaldo como o fim do sistema jagunço e suas "leis". Como vimos, é deste a palavra de ordem agenciadora da pulverização de uma ordem histórica cristalizada pela oligarquia rural do sertão-mundo, o que se faz patente neste sentenciamento riobaldiano: "Joca Ramiro morreu como o decreto de uma lei nova". ${ }^{39}$

A par de sua intervenção performática na história, Riobaldo é um sujeito político, empenhado em uma causa ambiental. Nesse papel, alerta a seu entrevistador que, se ele veio com a ilusão de descobrir um Brasil simultaneamente primitivo e idílico, a salvo do degradante impacto da modernização, é melhor que desista, pois o "paraíso perdido" já foi contaminado. No romance, a negatividade da mudança é, assim, denunciada:

O senhor sério tenciona devassar este mar de territórios, para sortimento de conferir o que existe? Tem seus motivos. Agora - digo por mim - o senhor vem, veio tarde. Tempos foram, os costumes demudaram. Quase que, de legítimo leal, pouco sobra, nem não sobra mais nada. Os bandos bons de valentões repartiram seu fim; muito que foi jagunço por aí

\footnotetext{
${ }^{35}$ ROSA. Grande sertão: veredas, p. 386.

${ }^{36}$ ROSA. Grande sertão: veredas, p. 297.

${ }^{37} \mathrm{O}$ jogo, a festa, o riso, a excentricidade, os limites nebulosos entre sanidade e loucura, entre morte e renovação, entre sagrado e profano, a ambivalente relatividade de tudo, o mundo às avessas ou à revelia são princípios que regem a "cosmovisão carnavalesca", no sentido que lhe confere Mikhail Bakhtin. Essa cosmovisão faz da arena onde ocorre o julgamento de Zé Bebelo um espaço de interatividade e desierarquização, aberto a mudanças e ao vir-a-ser. Ver BAKHTIN. Problemas da poética de Dostoiévski.

${ }^{38}$ ROSA. Grande sertão: veredas, p. 265.

${ }^{39}$ ROSA. Grande sertão: veredas, p. 297.
} 
pena, pede esmola. Mesmo os vaqueiros duvidam de vir no comércio vestidos de roupa inteira de couro, acham que o traje de gibão é feio e capiau. ${ }^{40}$

A denúncia à degradação ambiental do sertão decorre, dentre vários fatores, da violenta e desumana exploração da mão-de-obra semi-escrava tanto de trabalhadores rurais quanto de jagunços. Em razão dessa exploração, os grandes latifundiários puderam assegurar, durante muitas décadas, sua hegemonia política e econômica. O narrador do romance rosiano toma para si a missão heróica de combater o "mal da jagunçagem". Ele reflete, todavia, que, para fazê-lo, teria de conhecer o sistema jagunço a partir de suas próprias leis e lacunas, para, em seguida, combatê-lo. Nesse sentido, importa a premissa de Michel de Certeau, segundo o qual "se sale de las estructuras, pero para indicar lo que les falta, a saber la adhesión y la participación de los sometidos". ${ }^{41}$ De modo similar, Riobaldo irá, seguindo o ensinamento de Zé Bebelo, apropriar-se das armas, da ideologia e das leis dos latifundiários para empregá-las insurgentemente contra o próprio sistema jagunço. Assim, ele endossa e faz suas as palavras de seu mestre de guerra: "A gente tem de sair do sertão! mas só se sai do sertão é tomando conta dele a dentro..."42

Indagado por seu entrevistador sobre o sentido e sobre os limites cartográficos do sertão, Riobaldo lhe responde: "Lugar sertão se divulga: é onde os pastos carecem de fechos [...] O gerais corre em volta. Esses gerais são sem tamanho. Enfim, cada um o que quer aprova, o senhor sabe: pão ou pães, é questão de opiniães... O sertão está em toda parte". ${ }^{43}$ Essa é uma paradigmática passagem de Grande sertão: veredas, em que, ao descrever a ambígua localização do sertão para seu interlocutor, Riobaldo revela o caráter complexo, maleável, multíplice e desterritorializado do cenário que alicerça o sertão rosiano. Um "lugar sertão" que se desloca, desdobra-se e se entretece em redes metafórico-metonímicas para representar um mundo heterogêneo onde convivem Deus e o diabo, a violência e sua denúncia, a crueldade e a culpa, o local e o universal. Nesse traçado paradoxal onde tudo "é e não é ao mesmo tempo", descortina-se um espaço-tempo ambivalente, ubíquo e liminar, um "espaço sem lugares, tempo sem duração", para usar uma expressão de Althusser. ${ }^{44}$ Ao difundir e ampliar seu território, seus valores e denúncias, o "lugar sertão" rosiano patenteia uma concepção ambiental inovadora e reticular, em estreito diálogo com os dois romances supra mencionados e com as atuais pesquisas interdisciplinares sobre o tema, as quais deveriam, doravante, ter, em seu horizonte de expectativa, os paradigmas, as perspectivas e os equacionamentos que alicerçam as artes em geral e a literatura em particular.

\footnotetext{
${ }^{40}$ ROSA. Grande sertão: veredas, p.24.

41 "É possível sair das estruturas, desde que se aponte o que lhes falta, ou seja: a adesão e a participação dos subalternos." CERTEAU apud RICHARD. Resíduos y metáforas, p 221. Tradução minha.

${ }^{42}$ ROSA. Grande sertão: veredas, p. 260.

${ }^{43}$ ROSA. Grande sertão: veredas, p. 8.

${ }^{44}$ ALTHUSSER. Apud BHABHA. O local da cultura, p. 202.
} 


\section{A B STR A C T}

This article aims to identify some tangential aspects among the novels Vidas Secas, by Graciliano Ramos, As cidades invisiveis, by Italo Calvino, and Grande Sertão: Veredas, by Guimarães Rosa, especially those referring to the modalizing relations between literature and environment. Amongst the thematic diversity of the indicated novels it is subjacent the environmental conscience theme. In the last decades such theme has been receiving increasing attention not only by environmentalists but also by intellectuals and politicians. The focus on environmental degradation and on the implicit alert about the poor future life conditions in our planet reveals one of the main and incisive problems as challenges to the contemporaneous agenda. In this sense, the "lugar-sertão" of Guimarães Rosa reveals itself as been paradigmatic which, by revealing its territory, values, and denunciations, shows an innovative and reticular environmental conception, in a close dialogue with the current interdisciplinary researches on the theme. These researches should keep, from that moment on, in their expectative horizon, the paradigms, perspectives, and problems to solve that consolidate the arts in general and, specifically, the literature.

\section{KEYWORDS}

Environment. Literature. Contemporaneity.

\section{REFERÊNCIAS}

BAKHTIN, Mikhail. Problemas da poética de Dostoiévski. Trad. Paulo Bezerra. Rio de Janeiro: Forense-Universitária, 1981.

BARTHES, Roland. Aula. Trad. Leyla Perrone-Moisés. São Paulo: Cultrix, 1978.

BHABHA, Homi K. O local da cultura. Trad. Myriam Ávila et. al. Belo Horizonte: Editora UFMG, 1998.

CALVINO, Italo. As cidades invisíveis. Trad. Diogo Mainardi. São Paulo: Companhia das Letras, 1990.

CALVINO, Italo. Seis propostas para o próximo milênio. Trad. Ivo Barroso. São Paulo: Companhia das Letras, 1990.

CANDIDO, Antonio. Os bichos do subterrâneo. In: . Tese e antítese. São Paulo: Companhia Editora Nacional, 1964.

CANDIDO, Antonio. Tese e antítese. São Paulo: Companhia Editora Nacional, 1964.

CAPRA, Fritjorf. Alfabetização ecológica: o desafio para a educação no século XXI. In: TRIGUEIRO, André. Meio ambiente no século XXI. Rio de Janeiro: Sextante, 2003.

GUCCI, Guilhermo. Viajantes do maravilhoso. São Paulo: Companhia das Letras, 1992.

LINS, Álvaro. Valores e misérias das vidas secas. In: RAMOS, Graciliano. Vidas secas. São Paulo: Record, 1989. 
MELUCCI, Alberto. A invenção do presente: movimentos sociais nas sociedades complexas. Florianópolis: Vozes, 2001.

MOURÃO, Rui. Estruturas. Belo Horizonte: Tendência, 1969.

PAZ, Octavio. Traducción: literatura y literalidad. Barcelona: Tusquets, 1981.

POLO, Marco. O livro das maravilhas: a descrição do mundo. Porto Alegre: L\&PM, 1990.

RAMOS, Graciliano. Vidas secas. São Paulo: Martins, 1967.

RAVETTI, Graciela. Performances escritas. In: O corpo em performance. Belo Horizonte: FALE/UFMG, 2003.

RICHARD, Nelly. Resíduos y metáforas: ensayos de crítica cultural sobre el Chile de la transición. Santiago: Cuarto Propio, 1998.

ROSA, João Guimarães. Grande sertão: veredas. 21. ed. Rio de Janeiro: Nova fronteira, 1986.

SANTOS, Vânia Maria Nunes dos. O uso escolar das imagens de satélite: a socialização da ciência e tecnologia espacial. Disponível em: http://www.eca.usp.br/nucleos/nce/pdf/ 161.pdf. Acesso em: 20 out. 2006.

TRICART, Jean. Ecodinâmica. Rio de Janeiro: IBGE/SUPREN, 1977. Disponível em: www.autonomia.com.br/proposta/transdisciplinariedade.php-18k. Acesso em: 17 jun. 2007. 